\title{
Costs in English and Japanese legal procedure
}

\author{
by Satoko Niiya and Sam Jarman
}

It is the belief of Satoko Niiya and Sam Jarman that Japan is a non-litigious society because of high litigation costs and lengthy procedures. The authors explain the system of costs and changes that have been made and consider what still needs to be done.

$\int$ to apan is said to be a non-litigious society. Some say this is due to the general nature of Japanese people, who try to avoid confrontation or do not wish their problems to be exposed to the public and settled by an outsider. This is true not only of individuals but also of companies. Statistics show that, in 1996, $86 \%$ of companies choose private discussions and agreements as a means to settle disputes. The second most popular means is settlement in courts and, finally, judgments in courts. Others say that the non-litigious society exists because of a systematic problem in the Japanese civil and commercial procedure which has been criticised for its inefficiency in time costs.

Both reasons are correct, but the social reasons have, in the past, been over-emphasised and delays us from looking more carefully into the systematic problems. It is easy to say, for instance, that we Japanese like the ' $w a$ ' spirit, the spirit of peace and softness, which requires us to think about others first and to co-operate with each other. In the light of this spirit, to bring litigation against someone is an outrage.

However few cases have been encountered where a party decided not to sue because of that spirit. Individuals or companies, including foreign companies, quite often decide not to go to the Japanese courts simply because it would not be worthwhile. They are required to spend so much time and money during the procedure that they could not hope to be compensated for it, even if they win. Lawyers can sometimes find it difficult to encourage a client to go to court, even though they have a legitimate reason to sue.

\section{TIME AND COST IMPROVEMENTS}

Time incfficiencies in the civil and commercial procedure received the focus as one of the major issues to be improved, together with discovery procedure. The new civil procedure law, which was enacted on 1 January 1998, includes the principle of specdy procedure and many specific provisions to achieve this. We have not yet seen its effects, but hopefully it will be better.

On the other hand, discussion of cost seems to be much ignored. Some systems have been reviewed, for example, in 1995 the Japan Federation of Bar Associations tried to improve its regulation of legal fees in order to clarify the legal fee structure and make it transparent to the public. The commencement fee was also reduced, and success compensation increased, in order to make it easier to commence a law suit; the legal aid system is also now under review.

\section{Changes in Commercial Law}

In 1993 Japanese commercial law was changed. This included fixing the filing fee for a shareholder's derivative action at 8,200 yen $(£ 40)$, regardless of the amount of money the shareholder was claiming against the director. Also the legal fees can be charged to the company if the case is won. The calculation of the filing fee used to be based on the amount of the claim; the legal fee was not fully recoverable even if the plaintiff won. By making a claim, the price of the shareholder's shares would drop, but the damage would be less than paying the filing fee, other litigation expenses and legal fees!

The importance of derivative action as a means of corporate governance was recognised by the numerous illegal benefits given by companies to Sokaiya, the group who threatened companies that they would attend shareholders' meetings and cause trouble. Accordingly the various fees for derivative action were altered to make it easier to bring such an action (see Amicus Curiae, Issue 6, at p. 7 for further discussion of derivative action by shareholders).

\section{NOT WORTH GOING TO COURT}

Individuals or companies, including foreign companies, quite often decide not to go to the Japanese courts simply because it would not be worthwhile. They are required to spend so much time and money during the procedure that they could not hope to be compensated for it, even if they win. Lawyers can sometimes find it difficult to encourage a client to go to court, even though they have a legitimate reason to sue another.

This way of thinking, as applied to the derivative action, should also be applicable to civil and commercial procedure, but unfortunately it seems that, in general, the cost system is such that it is becoming more difficult for people to use lawyers and courts in Japan.

Costs constitute not merely a monetary problem but also prevent access to the Japanese judicial system. This article first examines the nature of costs incurred in civil and commercial procedure, and secondly who bears these costs. Finally, the question of whether this cost system is satisfactory to lawyers and to their clients is considered.

\section{COSTS IN CIVIL PROCEDURE}

There are two types of costs when suing in court: litigation costs, paid to the court, and legal fees, paid to the lawyer.

\section{Litigation costs}

Litigation costs are the costs to be paid to the court, this includes the filing fee for commencing a suit - the amount of which is set out in the Law of Civil Litigation Costs - and other costs such as those related to discovery or inspection of evidence, the daily salary of witnesses called upon by the court, fees to expert 
witnesses if called upon by a court order, travel costs, etc. The filing fees are paid by the plaintiff placing a stamp of the relevant amount on the writ. The filing fee calculation is based on the 'value of the object of litigation', which is normally the amount of the claim itself, if it is a monetary claim, or the value of the property if the object of the litigation is to seek the transfer of the title of property or any other specific performances relating to the property.

The law provides that the value of a claim should be set at 950,000 yen $(£ 4,000)$ in the event that the real value cannot be calculated, although the courts try, as far as possible, to specify the value by case law. For example, if the plaintiff is asking for a public apology from the defendant, the cost advertising of the apology is judged to be the value of the object. Based upon such values, the law of civil litigation costs provides for the percentage of such values to be used to calculate the filing fee. The percentage differs according to the value. For example, if the value of the claim is $100 \mathrm{~m}$ yen $(£ 500,000)$, the filing fee will be 410,000 yen $(£ 2,000)$. The filing fee includes everything for the entire procedure, prior to enforcement, in that stage of the court. The purpose of setting the filing fee quite high is to avoid an abuse of procedure. It may not be as expensive as English procedure if it goes all the way, but as a sum of money which the plaintiff has to pay at the outset, it is criticised as being too expensive, especially for individuals.

There is a legal aid system in Japan, but in 1993 the Japanese government spent $250 \mathrm{~m}$ yen $(£ 1.3 \mathrm{~m})$ on legal aid, whereas Britain spent something equivalent to 1.7 billion yen. It is not difficult to gucss that the legal aid system in Japan is not ideal. Experts' fees can vary a lot, depending on how prestigious the expert is, where the expert is from, etc. If the expert is based overseas, not only will costs for the opinion be included, but also travel expenses, hotel bills, etc. It is easy to imagine how expensive the litigation would be if the jurisdiction was in a Japanese court but the governing law was English law.

\section{Legal fee}

The legal fee is very important because it is paid to lawyers. There is no law regulating the amount of the legal fee but, as mentioned earlier, there is self-regulation by each local bar association. This sets out not the maximum, but the minimum charge, in order to avoid price competition among lawyers. Therefore, this is used a weapon against the client, on the basis that any discount would be a breach of the lawyer's obligation! In fact, the charge set out is really nothing more than a guide; there are no checks on how much clients are being charged.

Even though Japanese society is not litigious, the majority of lawyers' work consists of litigation, making them active in a very limited sphere of society. Since litigation is the main work of Japanese lawyers, the legal fee is normally based on the economic value of the object of the claim and the economic benefit the client. The fee is normally charged in two parts:

- at the beginning - the commencement fee - charged regardless of the result of the case; and

- at the end - success compensation - charged only when the case is successful.

The amount of the commencement fee and the success compensation are more or less decided under the regulation provided by each local bar association. For example, for the commencement fee, the Tokyo Bar Association regulation provides that $8 \%$ of the economic value of the claim is the standard amount of the commencement fee if the value is up to $3 \mathrm{~m}$ yen $(£ 15,000)$; $5 \%$ between 3 and $30 \mathrm{~m}$ yen $(£ 150,000)$; and then $3 \%$ between 30 and $300 \mathrm{~m}$ yen, above which it is $2 \%$.

The calculation of the success compensation is based on the eventual actual economic benefit to the client at the end of the procedure; it is exactly twice the percentage of the commencement fee. So, for example, if the claim is $100 \mathrm{~m}$ yen and the award is $80 \mathrm{~m}$ yen, the total fee that the client would have to pay would be:

- For the negotiation of contracts: $0.5 \%$.

- Commencement fee: up to 3myen@8\% x 3,000,000 =240,000; up to 30m@5\% x 27,000,000=1,350,000 up to 300m@3\% x 70,000,000=2,100,000:

Total commencement fee: 3,690,000 yen.

- Success compensation: up to 3m yen@16\% x 3,000,000 =480,000; up to 30m @ 10\% x 27,000,000=2,700,000; up to 300 million@6\% x 50,000,000=3,000,000: Total success compensation: 6,180,000 yen.

- TOTAL LEGAL FEE: $9,870,000$ yen (12\% of the total benefit) plus actual expenses.

Time-charging is also possible, and is the method preferred by foreign organisations. The regulations say that 10,000 yen is the minimum charge per hour, but that does not mean much in reality.

\section{WHO PAYS THE FEES?}

The litigation fee is, in principle, borne by the losing party. This will be ordered in the judgment. The legal fee is borne by each party who used a lawyer, regardless of the outcome, with the exception of the shareholder's derivative action mentioned above.

Usually in the case of a claim for damages, the court, in calculating quantum, recognises the lawyer's fee as a part of the damage. However, it is now established case law that the legal fees that the court will consider as part of the damages are limited to $10 \%$ of the damages and, more seriously, the court always tends to reduce the amount of damages, something which will further lower the legal costs to be paid by the losing party.

\section{MINIMUM CHARGES SET}

There is self-regulation by each local bar association. This sets out not the maximum, but the minimum charge, in order to avoid price competition among lawyers. Therefore, this is used as a weapon against the client, on the basis that any discount would be a breach of the lawyer's obligation! In fact, the charge set out is really nothing more than a guide; and there are no checks on how much clients are being charged.

The amount of damages recognised by courts in Japan is very low, because suing a person for damages is a means of recovering the actual damages and not a sanction against the defendant, nor a way of profiting from it. Therefore punitive damages and the like do not fall within the concept of 'damages' and are also against public policy. Damages are limited to the scope of adequate causation and the court's view of adequate causation is very limited. For example, in an argument as to whether anticipated profit could be included in damages or not, the Supreme Court ruled that:

'Such anticipated profit should be compensated only when the victim has proved that there was a special circumstance where, had not 
the tortious act occurred, the victim would have certainly made a profit from resale or other means, and that those were foreseen or should have been foreseen at the time of the act by the tort feasor.'

The burden of proof of this damage is on the plaintiff. Who can prove that I made a profit, or how can I prove that the other party could foresee that I would have made such profits?

\section{LEVEL OF DAMAGES}

It is clear when it comes to claims such as for damages based on sexual harassment, or on product liability where a person is injured (but not that seriously), that the amounts of damages tend to be very low.

One example was a sexual harassment case in which a young editor was harassed by her boss; he was also an editor and afraid that he might lose his position, because she was very good at her job. He made unpleasant sexual comments to her every day, finally causing her mental anxiety and eventually leading to her leaving the company. Later she sued the boss and the company for damages. It was a long and difficult case and made big news when the victim won the case. However, the amount of damages granted was $1 \mathrm{~m}$ yen $(£ 5,000)$ and the lawyer's fee amounted to $10 \%$ of this, i.e. 100,000 yen $(£ 500)$. About 10 female lawyers represented the victim; they won the case and the legal fee recognised by the judgment was 100,000 yen! This was at a time when sexual harassment awards in America were for sums such as $\$ 5 \mathrm{~m}$ and even $\$ 10 \mathrm{~m}$. Bringing a sexual harassment claim is already quite difficult for women, and is hardly worthwhile when there is so little compensation at the end.

\section{ACCESSIBILITY TO COURTS}

The initial legal fee should be lower so that more people can file their claim more easily. To avoid abuse of procedure is important, but it is more important first to open up the court to the public.

Product liability is the same, in the event of injury, damages will only be the hospital fee and maybe the daily salary lost for time off work. This is a small amount compared to the difficulty in proving that there is a defect in the product. Besides, in calculating damages, 'set-off of loss by benefit' is applied. That is, if the victim obtains a certain benefit derived from the tort itself, such sums can be set off against the damages. A typical such benefit is the insurance money paid out for an injury.

\section{Recovery of fees}

The system of not making legal fees payable by the losing party prevents people or companies from suing, as indicated by the number of claims brought about relating to shareholder's derivative actions and product liability. After the change of the commercial law in 1993 (decreasing the filing fee of the derivative action and allowing the winning party to claim legal fees from the company), there was a steep increase in the number of shareholders derivative actions: from 84 in 1993 to 145 in 1994. On the other hand, up until last year only one product liability case was brought based on the new product liability law, enacted on 1 July 1996, although the law was changed to make it easier for a consumer to sue a company. Admittedly, cost is not the only factor, but it is an important one.

It should be noted that the above only refers to cases with claims for damages; if the claim is not a damages claim - such as an other monetary clain, a claim for transfer of title of a certain property, etc. - the legal fee is not recoverable at all.
In summary, the relatively high filing fee that the plaintiff must pay at the outset has the effect of reducing abuse of procedure. Simply because the biggest part of the fees - the legal fee - is not recoverable, a party is not discouraged from undertaking activities which are unreasonable. Because the legal fee cannot be recovered from the losing party, lawyers are still entitled to be paid by their own client even if the client received nothing due to the insolvency of the losing party.

\section{ENFORCEMENT OF FOREIGN JUDGMENTS}

If the plaintiff obtains a monetary claim judgment in Britain and comes to Japan for the enforcement of such judgment, and the amount of the judgment includes the legal fee, it is possible that the legal fee to British lawyers will be recovered because the Japanese court does not, in principle, look at the substance of the foreign judgment'. However, if such a foreign judgment is attacked by the defendant, who claims that the judgment is against public policy, etc., the procedure can be long and the foreign party will not be able to recover the legal fee for their Japanese counsel.

\section{CONCLUSION}

The cost system under the Japanese civil and commercial procedure brings with it problems of accessibility to the court. The initial legal fee should be lower so that more people are able, more easily; to file claims. The avoidance of abuse of procedure is important, but it is more important first to open up the court to the public.

The legal fee - up to a reasonable amount - should be paid by the losing party. The Lawyer's Law, art. 1, states that lawyers should strive to achieve social justice and protection of human rights. This is the first thing Japanese lawyers are taught in training and they are reminded of it often during training. Although this author works in a law firm that deals mostly in corporate and commercial matters, that thought is still there and an effort is made to do pro bono work once in a while, to focus purely on the protection of human rights and achievement of social justice. Thus, it came as a shock to be told, at the beginning of an international litigation class in Cambridge last year, that:

'International commercial litigation is an investment; international businessmen are not doing litigation to achieve justice.'

To hear it so bluntly came as a surprise. Most Japanese lawyers would have the same reaction and this is precisely why the cost problem has not been as openly discussed as the time / efficiency problem.

Lawyers should not complain that they do not earn enough; there should not be any instance where a lawyer charges so much that a party gives up using the court. We have to be reminded of the reality that there are people who cannot file a lawsuit even though their rights are truly infringed, and there are companies who have decided to designate the courts of Delaware or England as those with jurisdiction, even when both parties are Japanese companies. Cost is certainly one of the reasons for this. E

Satoko Niiya and Sam Jarman

British Japanese Law Association 